\title{
Patients' attitude and practice toward reporting potential COVID-19 symptoms among the Al-Ahsa population in Saudi Arabia
}

\author{
MOHAMMED ALBARQI', A ABDULLAH ALMAQHAWI ${ }^{1, \mathrm{E}}$, AFNAN Y. ALRASHEED ${ }^{2, \mathrm{~B}, \mathrm{c}}$, \\ ORCID ID: 0000-0001-8510-8659 ORCID ID: 0000-0001-6035-1230 ORCID ID: 0000-0002-0021-3271 \\ MUNIRAH I. ALOHAYMID2, F, SHAYKHAH A. ALSAEED ${ }^{2, ~ в}$, HESSA S. AL-MOAIBED ${ }^{2, ~ F, ~}$ \\ ORCID ID: 0000-0002-6836-878X $\quad$ ORCID ID: 0000-0002-7338-1284 ORCID ID: 0000-0003-0648-298X \\ BETOOL A. ALKWITEM ${ }^{2, D}$, FATIMAH K. ALKHALIFAH ${ }^{2, A, ~ B}$, SHAIMA F. ALDOUGHAN ${ }^{2, c}$, \\ $\begin{array}{lll}\text { ORCID ID: 0000-0002-3786-6786 ORCID ID: 0000-0002-8543-6588 } & \text { ORCID ID: 0000-0002-6384-1507 }\end{array}$ \\ JAWAHER Y. ALRASHADA 2, B , AHMED ELSHEBINY3, 4, A, D, HANY S. ELBARBARY3, 4, D, E \\ ORCID ID: 0000-0001-6276-8881 ORCID ID: 0000-0001-9215-7088 ORCID ID: 0000-0001-8878-6367
}

\author{
${ }^{1}$ Department of Family Medicine and Community, College of Medicine, King Faisal University, Saudi Arabia \\ ${ }^{2}$ Medical Interns at King Faisal University in Al-Ahsa, Saudi Arabia \\ ${ }^{3}$ Department of Internal Medicine, Faculty of Medicine, Menoufia University, Egypt \\ ${ }^{4}$ Department of Internal Medicine, College of Medicine, King Faisal University, Saudi Arabia
}

A - Study Design, B - Data Collection, C - Statistical Analysis, D - Data Interpretation, E - Manuscript Preparation, F - Literature Search, $\mathbf{G}-$ Funds Collection

Summary Background. The new coronavirus pandemic, which appeared at the end of the year 2019, was the greatest in recent decades, and it affected almost all countries and economies, causing a highly significant number of deaths.

Objectives. This study aimed to evaluate patients' knowledge and attitude when experiencing potential COVID-19 symptoms toward reporting their illness and following viral preventive precautions.

Material and methods. A cross-sectional study conducted among the general population in Al-Ahsa, Eastern region, Saudi Arabia. A self-administered questionnaire distributed among the general population, divided into three parts: socio-demographic characteristics, previous COVID-19 infection and attitude toward experiencing COVID-19 symptoms. A total of 504 responses collected in this study from December 15, 2020 to January 15, 2021.

Results. We found that $31.7 \%$ were positive among the participants who did COVID-19 testing (48.8\%). The level of knowledge showed that more than half (52.2\%) were classified at a low knowledge level, while the rest were classified as good (47.8\%). Regarding attitude, nearly two-thirds (64.1\%) showed a negative attitude, while $35.9 \%$ showed a positive attitude. The workplace during the pandemic and family history of COVID-19 were the factors associated with both good knowledge and a positive attitude.

Conclusions. The knowledge and attitude toward reporting potential COVID-19 symptoms were generally suboptimal. Male participants, holders of a university degree in the medical field, health practitioners or having a family member working in the medical field demonstrated better knowledge, while those who had a COVID-19 test and those with a family history of the disease positively influenced the attitude.

Key words: COVID-19, attitude, knowledge, infections.

Albarqi M, Almaqhawi A, AlRasheed AY, Alohaymid MI, AISaeed SA, Al-Moaibed HS, Alkwitem BA, AlKhalifah FK, AlDoughan SF, AlRashada JY, Elshebiny A, Elbarbary HS. Patients' attitude and practice toward reporting potential COVID-19 symptoms among the Al-Ahsa population in Saudi Arabia. Fam Med Prim Care Rev 2021; 23(3): 261-268, doi: https://doi.org/10.5114/fmpcr.2021.108186.

\section{Background}

At the end of 2019 and the beginning of 2020, a novel virus started hitting different regions worldwide and resulted in a crisis affecting all aspects of life. The newly discovered virus is a new member of the larger coronavirus family, which causes a wide range of diseases ranging from the common cold to more severe diseases, such as Middle East Respiratory Syndrome (MERS-CoV) and Severe Acute Respiratory Syndrome (SARS-CoV) [1]. Coronavirus disease 19 (COVID-19) is a highly contagious virus with rapid human-to-human transmission [2].

Symptoms of COVID-19 range from no symptom to symptoms that are mild, severe, critical or even lethal, with most infections being mild [3]. The most common clinical features have been described by Michelen et al., including fever, fatigue, chills, muscle pain, cough, loss of taste or smell, difficulty in breathing and sore throat [4]. Pneumonia appears to be the most severe frequent manifestation of infection, characterized primarily by fever, cough, dyspnea and bilateral infiltrates on chest imaging [5-7].

COVID-19 has an infectious period that lasts from two days before the development of signs and symptoms to ten days after symptoms arise. It is important to note that even asymptomatic individuals could be infectious [8].

COVID-19 can be diagnosed using real-time reverse transcription-polymerase chain reaction (RT-qPCR) [9]. Regarding the difficulty in early detection of COVID-19, the infection is further confounded by the disease's lack of specific clinical features. Some patients presented with only mild or no respiratory symptoms; others were without fever or symptoms of pneumonia [10]. Thus, it is challenging to promptly identify and isolate infection sources in a conventional emergency room or during the primary care process. 
Patient knowledge and attitude toward most symptoms of the novel coronavirus and their experience of these symptoms, including recovery, are essential research questions. The government of Saudi Arabia continues to act regarding infection control and prevention of COVID-19. Few studies have discussed the attitude and practice of the population toward COVID-19 infection among the general population of Saudi Arabia. The assessment of these parameters will help health decision-makers in their plans of action to overcome the changing situation of the epidemic.

A nationwide Saudi study of knowledge, attitude and practice regarding COVID-19 published in September 2020 showed a satisfactory knowledge level, attitude and practical implementation of practices to overcome the COVID-19 pandemic in Saudi Arabia. Additionally, demographic variables, such as education level and age, were significantly related to improved knowledge, attitudes and practices in the population [11].

To our knowledge, no studies have been published in the Al-Ahsa governorate addressing the population's knowledge, attitude and practice toward the epidemic. Additionally, the specific behavior of persons toward reporting COVID-19 has not been well assessed in most previous studies.

\section{Objectives}

This study aimed to evaluate patients' knowledge and attitude when experiencing potential COVID-19 symptoms toward reporting their illness and following viral preventive precautions.

\section{Material and methods}

\section{Study design}

The current study is a questionnaire-based observational cross-sectional study of the prevalence of suspected COVID-19 symptoms in the general population of the Al-Ahsa governorate from December 15, 2020 until January 15, 2021. The participants were asked if they felt any COVID-19 symptoms within the previous six months.

\section{Inclusion and exclusion criteria}

The general population of this study was defined as all the population of Al-Ahsa from the age of 18-65, which included Saudi citizens and non-Saudi residents, as well as healthcare and non-healthcare workers. On the other hand, the exclusion criteria were those under 18 years of age and those above 65 years of age. Mentally incapable people were also excluded from this study.

\section{Sampling and data collection}

The minimum sample size was 385 , based on the computer software (EPI_INFO) sample size calculator with a confidence level of $95 \%$ (sample size $=\mathrm{Z} 2 \times(p) \times(1-p) / \mathrm{c} 2)$. An estimation of receiving $50 \%$ of responses was calculated. For this reason, the survey was sent to 800 participants. However, a total of 504 responses were obtained, with a response rate of $63 \%$.

The sample was collected utilizing a non-probability convenience sampling technique. An online Google questionnaire was used to design the questionnaire. A link to this survey was then distributed via social media (Twitter, Facebook and WhatsApp) to meet the target sample size. The questionnaire was valid and reliable, as it was taken from previous research, and there were some modifications to fit the study. It contained a part for the informed consent and ensuring the privacy of the participants. It also contained the demographical data and questions needed to fulfill the objectives of the study. As the survey was open for one month, the sample size increased, as many participants took part in this study, which resulted in a final sample size of 504.

\section{Questionnaire (assessment tool)}

The researchers developed a valid and reliable questionnaire using modified questionnaires from previous studies [12-19]. Consultants also reviewed testing reliability via a pilot study of the first 30 responses utilizing Cronbach's alpha test. The study questionnaire consisted of 25 close-ended questions in three sections. The first section was designed to check the demographic and education data (Table 1). The second section tested participants' knowledge of COVID-19 and if they had previous exposure to COVID-19 (Table 2). The participants with positive COVID-19 test results verified the results by providing their mobile numbers. The study was done during the second wave of COVID-19, which was a continuation of the first wave. However, as the participants were asked if they had any COVID-19 symptoms in the previous six months, the first wave was also included in this study. The last section assessed the prevalence of COVID-19 symptoms among the studied groups and the patients' attitudes toward these symptoms, including notification of health authorities and adherence to infection prevention measures (Table 4, 5). Furthermore, we included questions to assess the reasons for possible non-adherence to health authorities' guidelines regarding dealing with potential COVID-19 symptoms.

\section{Questionnaire criteria}

The assessment of participants' knowledge and attitude toward potential COVID-19 symptoms comprised 3 and 8 questions, respectively, described in Table 3 and Table 4, where we identified and marked the correct answers (correct answers were coded as 1 , while the incorrect answers were coded 0 ). Knowledge questions had multiple response answers of three correct answers or more, generating 3 items for knowledge. Attitude questions had multiple responses answers with three correct answers or more, generating 9 attitude items. The total score was calculated by adding all questions separately for knowledge ( 5 items) and attitude ( 9 items). The knowledge score range was from 1 to 5 points, while the attitude score range was from 0 to 9 points, which indicates that the higher the score, the higher the knowledge and attitude regarding $\mathrm{CO}$ VID-19. A mean score was used as a cutoff point to determine the level of knowledge and attitude. As a result, participants were classified as having poor knowledge or a negative attitude if the scores were equal to or below the mean knowledge score.

\section{Ethics approval and consent to participate}

The research followed all ethical considerations, and approval was obtained from King Faisal University, Saudi Arabia. The committee's reference number is 80-10-2020. All patients were informed, and written consent was obtained from all participants after explaining the study's aim.

\section{Statistical analysis}

Data was elaborated upon with numbers (percentages) for all qualitative variables. On the other hand, mean, standard deviation and median (min-max) were used to elaborate all quantitative variables. The Chi-square test was used to compare socio-demographic variables to being tested for COVID-19. The comparison between the knowledge and attitude score concerning participants' socio-demographic characteristics was conducted using the Mann-Whitney $U$ test or Kruskal-Wallis test when appropriate. Normality, statistical interactions and collinearity (i.e. variance inflation factor) were also assessed with the Kolmogorov-Smirnov and Shapiro-Wilk test. Based on the normality test, the data followed abnormal distribution. 
Thus, non-parametric tests were applied between comparisons. A $p$-value $<0.05$ was considered statistically significant. Correlation procedures were also conducted to determine the linear relationship between the knowledge and attitude score. All statistical data was analyzed using Statistical Package for the Social Sciences (SPSS) version 21 Armonk, New York, IBM Corporation.

\section{Results}

We recruited 504 participants to measure the knowledge and attitude toward reporting potential COVID-19 symptoms. Table 1 presents the socio-demographic characteristics of the 504 respondents. The age range was 18 to 65 years old, with $70 \%$ in the younger age group. Females dominated over males (69.6\% vs $30.4 \%)$, with nearly all (97.6\%) being Saudis, and more than half were not married. Concerning their educational level, nearly half of them (47.2\%) had a university degree in a non-medical field, and $30.8 \%$ had a high school or lesser degree. Furthermore, more than half $(51.6 \%)$ lived in Hofuf with 4 to 6 family members. With regards to their workplace during
COVID-19, 15.7\% were working remotely, while 51.6\% were unemployed. The proportion of participants who stated that their family members worked in the medical field was $37.7 \%$. When measuring the relationship between the socio-demographic characteristics and being tested for COVID-19, it was found that age group $\left(\chi^{2}=10.061 ; p=0.007\right)$, gender $\left(\chi^{2}=52.318\right.$; $p<0.001)$, nationality $\left(\chi^{2}=8.060 ; p=0.005\right)$, education level $\left(\chi^{2}=9.702 ; p=0.021\right)$, residence area $\left(\chi^{2}=7.763 ; p=0.021\right)$ and workplace during the pandemic $\left(\chi^{2}=40.537 ; p<0.001\right)$ showed a significant relationship with those tested for COVID-19.

Table 2 shows the prevalence of COVID-19 and other related behaviors of participants toward the pandemic. The prevalence of participants who underwent COVID-19 testing was $48.8 \%$. Among them, $31.7 \%$ tested positive. The proportion of respondents with a family history of COVID-19 was $53.2 \%$. Furthermore, $57 \%$ had recovered within a few days after experiencing symptoms, and a similar proportion (56.2\%) reported to feel normal after recovery. $37.9 \%$ indicated that they were not afraid of COVID-19 infection, whilst others were a little afraid (34.5\%) or somewhat afraid (16.9\%).

\begin{tabular}{|c|c|c|c|c|c|}
\hline \multirow[t]{2}{*}{ Study variables } & \multirow{2}{*}{$\begin{array}{l}\text { Overall } \\
n(\%) \\
(n=504)\end{array}$} & \multicolumn{2}{|c|}{ Tested for COVID-19 } & \multirow[t]{2}{*}{$x^{2}$} & \multirow[t]{2}{*}{$p^{*}$} \\
\hline & & $\begin{array}{l}\text { Yes } \\
n(\%) \\
(n=246)\end{array}$ & $\begin{array}{l}\text { No } \\
n(\%) \\
(n=258)\end{array}$ & & \\
\hline $\begin{array}{l}\text { Age group } \\
18-35 \text { years } \\
36-50 \text { years } \\
51-65 \text { years }\end{array}$ & $\begin{array}{l}352(69.8 \%) \\
115(22.8 \%) \\
37(7.3 \%)\end{array}$ & $\begin{array}{l}188(76.4 \%) \\
45(18.3 \%) \\
13(5.3 \%)\end{array}$ & $\begin{array}{l}164(63.6 \%) \\
70(27.1 \%) \\
24(9.3 \%)\end{array}$ & 10.061 & $0.007 * *$ \\
\hline $\begin{array}{l}\text { Gender } \\
\text { male } \\
\text { female }\end{array}$ & $\begin{array}{l}153(30.4 \%) \\
351(69.6 \%)\end{array}$ & $\begin{array}{l}112(45.5 \%) \\
134(54.5 \%)\end{array}$ & $\begin{array}{l}41 \text { (15.9\%) } \\
217(84.1 \%)\end{array}$ & 52.318 & $<0.001 * *$ \\
\hline $\begin{array}{l}\text { Nationality } \\
\text { Saudi } \\
\text { Non-Saudi }\end{array}$ & $\begin{array}{l}492(97.6 \%) \\
12(2.4 \%)\end{array}$ & $\begin{array}{l}245(99.6 \%) \\
1(0.40 \%)\end{array}$ & $\begin{array}{l}247 \text { (95.7\%) } \\
11(4.3 \%)\end{array}$ & 8.060 & $0.005^{* *}$ \\
\hline $\begin{array}{l}\text { Marital status } \\
\text { unmarried } \\
\text { married }\end{array}$ & $\begin{array}{l}263(52.2 \%) \\
241(47.8 \%)\end{array}$ & $\begin{array}{l}136(55.3 \%) \\
110(44.7 \%)\end{array}$ & $\begin{array}{l}127(49.2 \%) \\
131(50.8 \%)\end{array}$ & 1.853 & 0.173 \\
\hline $\begin{array}{l}\text { Education level } \\
\text { high school or below } \\
\text { university, non-medical } \\
\text { university, medical } \\
\text { postgraduate }\end{array}$ & $\begin{array}{l}155(30.8 \%) \\
238(47.2 \%) \\
92(18.3 \%) \\
19(3.8 \%)\end{array}$ & $\begin{array}{l}67(27.2 \%) \\
112(45.5 \%) \\
58(23.6 \%) \\
9(3.7 \%)\end{array}$ & $\begin{array}{l}88(34.1 \%) \\
126(48.8 \%) \\
34(13.2 \%) \\
10(3.9 \%)\end{array}$ & 9.702 & $0.021 * *$ \\
\hline $\begin{array}{l}\text { Residence area } \\
\text { Hofuf } \\
\text { Al Mubarraz } \\
\text { Al Oyoun and Al Jafr }\end{array}$ & $\begin{array}{l}250(51.6 \%) \\
155(30.8 \%) \\
89(17.7 \%)\end{array}$ & $\begin{array}{l}115(46.7 \%) \\
90(36.6 \%) \\
41(16.7 \%)\end{array}$ & $\begin{array}{l}145(56.2 \%) \\
65(25.2 \%) \\
48(18.6 \%)\end{array}$ & 7.763 & $0.021 * *$ \\
\hline $\begin{array}{l}\text { Number of family members } \\
1-3 \\
4-6 \\
\geq 7\end{array}$ & $\begin{array}{l}88(17.5 \%) \\
238(47.2 \%) \\
178(35.3 \%) \\
\end{array}$ & $\begin{array}{l}42(17.1 \%) \\
114(46.3 \%) \\
90(36.6 \%)\end{array}$ & $\begin{array}{l}46(17.8 \%) \\
124(48.1 \%) \\
88(34.1 \%) \\
\end{array}$ & 0.339 & 0.844 \\
\hline $\begin{array}{l}\text { Workplace during pandemic } \\
\text { unemployed } \\
\text { work at home (remotely) } \\
\text { I work outside, and I have been in contact with } \\
\text { many people } \\
\text { I work outside, and I have been in contact with few } \\
\text { people } \\
\text { health practitioner }\end{array}$ & $\begin{array}{l}260(51.6 \%) \\
79(15.7 \%) \\
74(14.7 \%) \\
\\
42(8.3 \%) \\
49(9.7 \%) \\
\end{array}$ & $\begin{array}{l}98(39.8 \%) \\
37(15.0 \%) \\
53(21.5 \%) \\
22(8.9 \%) \\
36(14.6 \%)\end{array}$ & $\begin{array}{l}162(62.8 \%) \\
42(16.3 \%) \\
21(8.1 \%) \\
20(7.8 \%) \\
13(5.0 \%) \\
\end{array}$ & 40.537 & $<0.001 * *$ \\
\hline $\begin{array}{l}\text { Family members working in the medical field } \\
\text { yes } \\
\text { no }\end{array}$ & $\begin{array}{l}190(37.7 \%) \\
314(62.3 \%)\end{array}$ & $\begin{array}{l}91(37.0 \%) \\
155(63.0 \%)\end{array}$ & $\begin{array}{l}99(38.4 \%) \\
159(61.6 \%)\end{array}$ & 0.102 & 0.749 \\
\hline
\end{tabular}

* $p$-value calculated using the Chi-square test, ${ }^{* *}$ significant at a level of $p<0.05$. 


\begin{tabular}{|c|c|}
\hline Variables & $n(\%)$ \\
\hline $\begin{array}{l}\text { Tested for COVID-19 } \\
\text { yes } \\
\text { no }\end{array}$ & $\begin{array}{l}246(48.8 \%) \\
258(51.2 \%)\end{array}$ \\
\hline $\begin{array}{l}\text { COVID-19 results }(n=246) \\
\text { negative } \\
\text { positive }\end{array}$ & $\begin{array}{l}168(68.3 \%) \\
78(31.7 \%) \\
\end{array}$ \\
\hline $\begin{array}{l}\text { Family history of COVID-19 } \\
\text { yes } \\
\text { no }\end{array}$ & $\begin{array}{l}268(53.2 \%) \\
236(46.8 \%)\end{array}$ \\
\hline $\begin{array}{l}\text { If you had any of the above symptoms } \\
\text { I recovered within a few days } \\
\text { the symptoms worsened } \\
\text { admitted to hospital } \\
\text { no symptoms }\end{array}$ & $\begin{array}{l}285(56.5 \%) \\
7(1.4 \%) \\
5(1.0 \%) \\
207(41.1 \%) \\
\end{array}$ \\
\hline $\begin{array}{l}\text { Feeling after recovery } \\
\text { normal } \\
\text { still not feeling well } \\
\text { no symptoms }\end{array}$ & $\begin{array}{l}283(56.2 \%) \\
14(2.8 \%) \\
207(41.1 \%) \\
\end{array}$ \\
\hline $\begin{array}{l}\text { Are you afraid of COVID-19 infection? } \\
\text { very afraid } \\
\text { somewhat afraid } \\
\text { a little afraid } \\
\text { not afraid at all } \\
\text { I do not know }\end{array}$ & $\begin{array}{l}28(5.6 \%) \\
85(16.9 \%) \\
174(34.5 \%) \\
191(37.9 \%) \\
26(5.2 \%)\end{array}$ \\
\hline
\end{tabular}

Figure 1 depicted the symptoms experienced in the past three months. It revealed that the most mentioned symptoms were headache $(34.9 \%)$ followed by fatigue $(28.6 \%)$ and sore throat $(20.4 \%)$, while the least mentioned was difficulty in breathing or shortness of breath (8.3\%).

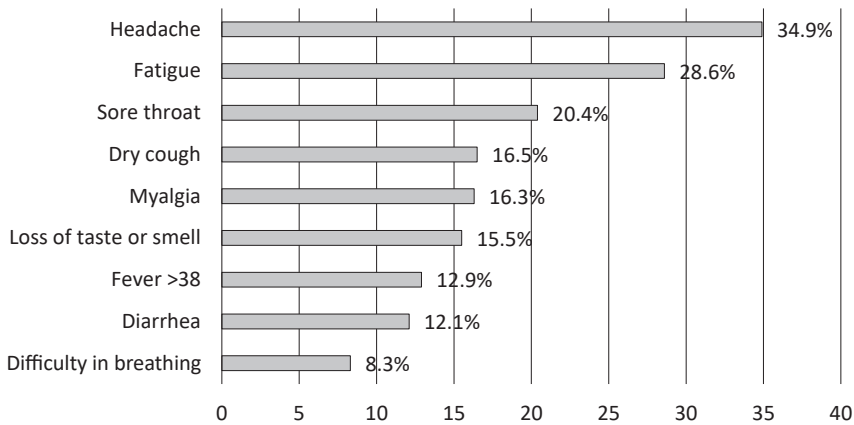

Figure 1. Symptoms in the past three months of participants from the Al-Ahsa population during the period from December 15 to January 15, 2020

Table 3 describes the assessment of knowledge toward COVID-19. The proportion of participants who had received information about COVID-19 was $78.6 \%$. The most frequently mentioned means of COVID-19 transmission was through the respiratory droplets of infected persons when sneezing or coughing $(85.3 \%)$, followed by direct contact with infected persons $(63.7 \%)$ and contact with contaminated objects and surfaces (46.8\%). Furthermore, nearly two-thirds (63.9\%) indicated that it might take up to 2 weeks for the incubation period of COVID-19.

Table 4 shows the assessment of attitude toward COVID-19. Based on the results, it was found that the most stated action to be taken when experiencing symptoms was self-isolation (33.9\%) and by drinking plenty of water and eat nutritious foods (23.2\%). Likewise, nearly $60 \%$ were not afraid to go for a checkup when they felt symptoms despite being ostracized, and most (90.1\%) would not hide the matter when they suspected that they contracted the virus. The proportion of respondents who became interested in health education about COVID-19, those who started exercising and eat healthier and those who stopped smoking during the pandemic were $65.7 \%, 38.1 \%$ and $7.1 \%$, respectively. The prevalence of respondents who were willing to get the COVID-19 vaccination was $12.5 \%$.

\begin{tabular}{|c|c|}
\hline Knowledge statement & $n(\%)$ \\
\hline $\begin{array}{l}\text { Received information about COVID-19 } \\
\text { yes* } \\
\text { no } \\
\text { not sure }\end{array}$ & $\begin{array}{l}396(78.6 \%) \\
14(2.8 \%) \\
94(18.7 \%)\end{array}$ \\
\hline $\begin{array}{l}\text { How does COVID-19 spread? }{ }^{\dagger} \\
\text { through droplets of infected persons when } \\
\text { sneezing or coughing* } \\
\text { direct contact with infected persons* } \\
\text { contact with contaminated objects and surfaces* } \\
\text { eating contaminated food }\end{array}$ & \begin{tabular}{|l}
$430(85.3 \%)$ \\
$321(63.7 \%)$ \\
$236(46.8 \%)$ \\
$34(6.7 \%)$ \\
\end{tabular} \\
\hline $\begin{array}{l}\text { What is the incubation period of COVID-19? } \\
\text { three days or less } \\
\text { a week } \\
\text { it may take up to } 2 \text { weeks* } \\
\text { I do not know }\end{array}$ & \begin{tabular}{|l|}
$78(15.5 \%)$ \\
$75(14.9 \%)$ \\
$322(63.9 \%)$ \\
$29(5.8 \%)$
\end{tabular} \\
\hline
\end{tabular}

* Indicates correct answers, † variable with multiple answers.

Table 4. Assessment of attitude of participants from the

Al-Ahsa population toward COVID-19 $(n=504)$ Attitude statement $n(\%)$

Action to be taken when experience symptoms ${ }^{\dagger}$

I did not do anything

isolate myself at home*

drink plenty of fluids and eat nutritious foods

taking vitamins

herbal remedies

notify 937 communication center*

I visited the nearest primary $\mathrm{HCC}$ and took all precautions*

I ignored my symptoms, as I thought it was the common flu

$212(42.1 \%)$

$171(33.9 \%)$

$117(23.2 \%)$

$98(19.4 \%)$

$54(10.7 \%)$

$44(8.7 \%)$

$94(18.7 \%)$

If you feel any of the symptoms, are you afraid to

go for a test for fear of being bullied or ostracized?

yes

no*

maybe

I do not know

$33(6.5 \%)$

If you suspect that you are infected with the

virus, do you think you should hide the matter from people around you so you will not be bullied or ostracized?

yes

no*

maybe

I do not know

$10(5.6 \%)$

$295(58.5 \%)$

$15(3.0 \%)$

$146(29.0 \%)$

During this pandemic, have you become interested in health education about viruses, especially COVID-19?

yes*

neutral

not interested

$331(65.7 \%)$

$167(33.1 \%)$

$6(1.2 \%)$

During this pandemic, has your life been affected, and have you started exercising and eat healthier? yes*

neutral

no, I did not change

During this pandemic, if you were a smoker, did you stop smoking so that you would not get infected easily?

yes*

no, I do not see the relation

I do not smoke* 


\begin{tabular}{|c|c|}
\hline Attitude statement & $n(\%)$ \\
\hline $\begin{array}{l}\text { Are you willing to get the vaccine? } \\
\text { yes* } \\
\text { no } \\
\text { I have not decided yet }\end{array}$ & $\begin{array}{l}63(12.5 \%) \\
52(10.3 \%) \\
389(77.2 \%)\end{array}$ \\
\hline
\end{tabular}

$*$ Indicates correct answers, + variable with multiple answers. HCC - Health Care Center.

\begin{tabular}{|c|c|}
\hline Knowledge and attitude parameters & $n(\%)$ \\
\hline $\begin{array}{l}\text { Total knowledge score } \\
\text { mean } \pm \text { SD } \\
\text { median (min-max) }\end{array}$ & $\begin{array}{l}3.38 \pm 1.14 \\
1(1-5)\end{array}$ \\
\hline $\begin{array}{l}\text { Level of knowledge } \\
\text { poor } \\
\text { good }\end{array}$ & $\begin{array}{l}263(52.2 \%) \\
241(47.8 \%)\end{array}$ \\
\hline $\begin{array}{l}\text { Total attitude score } \\
\text { mean } \pm \text { SD } \\
\text { median (min-max) }\end{array}$ & $\begin{array}{l}4.16 \pm 1.53 \\
4(0-8)\end{array}$ \\
\hline $\begin{array}{l}\text { Level of attitude } \\
\text { negative } \\
\text { positive }\end{array}$ & $\begin{array}{l}323(64.1 \%) \\
181(35.9 \%)\end{array}$ \\
\hline
\end{tabular}

Table 5 presents the prevalence of knowledge and attitude toward COVID-19. It revealed that the total mean knowledge score was 3.38 (SD 1.14), with more than half (52.2\%) classified as having poor knowledge, while the rest were good (47.8\%). Regarding attitude, the total mean attitude score was 4.16 (SD 1.53), with nearly two-thirds (64.1\%) classified as having a negative attitude, while $35.9 \%$ classified as having a positive attitude. Figure 2 depicted the correlation between the knowledge and attitude scores. It was found that the correlation between the knowledge and attitude scores was not statistically significant $(r=0.168 ; p=0.061)$.

When measuring the association between knowledge and attitude scores concerning the socio-demographic characteristics of participants (Table 6), it appeared that being male ( $T=2.248 ; p=0.020)$, having a university degree in the medical field $(F=8.109 ; p<0.001)$, being a health practitioner $(F=6.417 ; p<0.001)$ and having family members working in the medical field were observed to have a significantly higher mean knowledge score than their counterparts. On the other hand, those respondents with a family history of COVID-19 showed a significantly less mean knowledge score $(T=-2.483$; $p=0.013)$. Those who had been tested for COVID-19 $(T=7.324$; $p<0.001)$ and those who had a family history of COVID-19 exhibited a significantly higher mean attitude score, while being a resident of Hofuf $(F=4.318 ; p=0.014)$ and those who work at home $(F=3.705 ; p=0.010)$ exhibited a significantly lower mean attitude score. Other socio-demographic characteristics, including age group, marital status and the number of family members, did not show a significant association when compared to both knowledge and attitude scores $(p>0.05)$.

$r=0.168 ; p=0.061 ;$ not significant

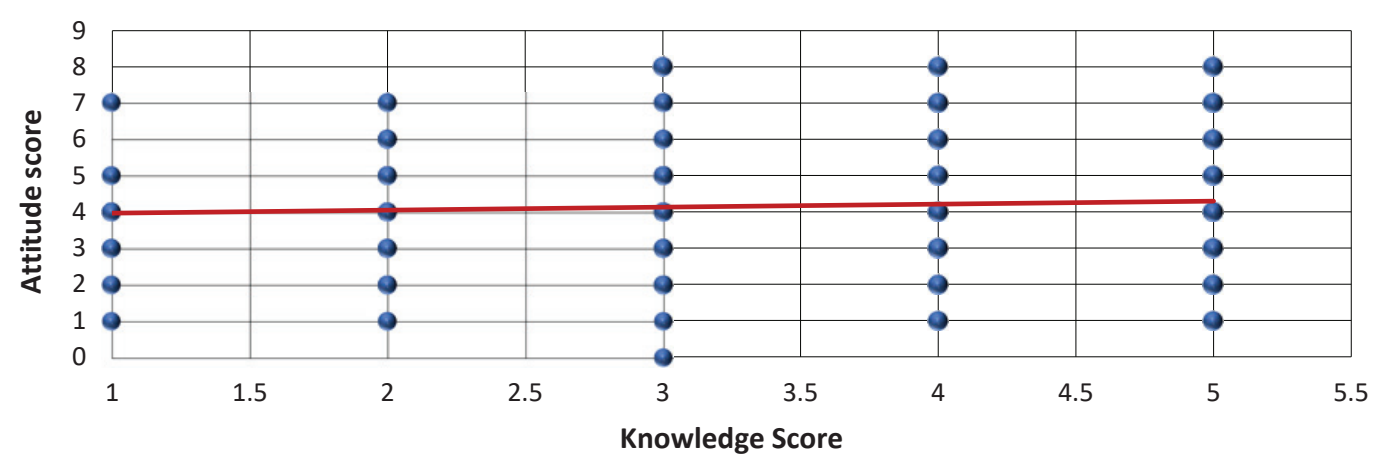

Figure 2. Correlation (Pearson-r) between the knowledge and attitude scores of participants from the Al-Ahsa population during the period from December 15 to January 15, 2020

\begin{tabular}{|c|c|c|c|c|}
\hline \multirow[t]{2}{*}{ Factor } & \multicolumn{2}{|l|}{ Knowledge } & \multicolumn{2}{|l|}{ Attitude } \\
\hline & $\begin{array}{l}\text { Total score (5) } \\
\text { Mean } \pm \text { SD }\end{array}$ & $\begin{array}{l}F / T \text {-test } \\
p\end{array}$ & $\begin{array}{l}\text { Total score (8) } \\
\text { Mean } \pm \text { SD } \\
\end{array}$ & $\begin{array}{l}F / T \text {-test } \\
p\end{array}$ \\
\hline $\begin{array}{l}\text { Age group }{ }^{\mathrm{a}} \\
18-35 \text { years } \\
>35 \text { years }\end{array}$ & $\begin{array}{l}3.69 \pm 1.16 \\
3.37 \pm 1.11\end{array}$ & $\begin{array}{l}T=0.187 \\
0.798\end{array}$ & $\begin{array}{l}4.13 \pm 1.56 \\
4.24 \pm 1.44\end{array}$ & $\begin{array}{l}T=0.463 \\
0.301\end{array}$ \\
\hline $\begin{array}{l}\text { Gender }^{\mathrm{a}} \\
\text { male } \\
\text { female }\end{array}$ & $\begin{array}{l}3.56 \pm 1.18 \\
3.31 \pm 1.12\end{array}$ & $\begin{array}{l}T=2.248 \\
0.020 * *\end{array}$ & $\begin{array}{l}4.33 \pm 1.64 \\
4.09 \pm 1.47\end{array}$ & $\begin{array}{l}T=1.614 \\
0.086\end{array}$ \\
\hline $\begin{array}{l}\text { Marital status }{ }^{a} \\
\text { unmarried } \\
\text { married }\end{array}$ & $\begin{array}{l}3.37 \pm 1.14 \\
3.39 \pm 1.15 \\
\end{array}$ & $\begin{array}{l}T=-0.211 \\
0.845\end{array}$ & $\begin{array}{l}4.09 \pm 1.58 \\
4.24 \pm 1.47 \\
\end{array}$ & $\begin{array}{l}T=-1.125 \\
0.139\end{array}$ \\
\hline $\begin{array}{l}\text { Education level }^{\mathrm{b}} \\
\text { high school or below } \\
\text { university, non-medical } \\
\text { university, medical } \\
\text { postgraduate }\end{array}$ & $\begin{array}{l}3.25 \pm 1.19 \\
3.28 \pm 1.12 \\
3.90 \pm 0.99 \\
3.32 \pm 1.06\end{array}$ & $\begin{array}{l}F=8.109 \\
<0.001 * *\end{array}$ & $\begin{array}{l}4.17 \pm 1.55 \\
4.14 \pm 1.44 \\
4.09 \pm 4.64 \\
4.68 \pm 1.89\end{array}$ & $\begin{array}{l}F=0.812 \\
0.564\end{array}$ \\
\hline
\end{tabular}




\begin{tabular}{|c|c|c|c|c|}
\hline \multirow[t]{2}{*}{ Factor } & \multicolumn{2}{|l|}{ Knowledge } & \multicolumn{2}{|l|}{ Attitude } \\
\hline & $\begin{array}{l}\text { Total score (5) } \\
\text { Mean } \pm \text { SD }\end{array}$ & $\begin{array}{l}F / T \text {-test } \\
p\end{array}$ & $\begin{array}{l}\text { Total score (8) } \\
\text { Mean } \pm \text { SD }\end{array}$ & $\begin{array}{l}F / T \text {-test } \\
p\end{array}$ \\
\hline $\begin{array}{l}\text { Residence area }^{\text {b }} \\
\text { Hofuf } \\
\text { Al Mubarraz } \\
\text { Al Oyoun and Al Jafr }\end{array}$ & $\begin{array}{l}3.36 \pm 1.10 \\
3.35 \pm 1.13 \\
3.52 \pm 1.27\end{array}$ & $\begin{array}{l}F=0.744 \\
0.339\end{array}$ & $\begin{array}{l}4.00 \pm 1.49 \\
4.21 \pm 1.45 \\
4.54 \pm 1.72\end{array}$ & $\begin{array}{l}F=4.318 \\
0.014^{* *}\end{array}$ \\
\hline $\begin{array}{l}\text { Number of family members } \\
1-3 \\
4-6 \\
\geq 7\end{array}$ & $\begin{array}{l}3.35 \pm 1.31 \\
3.34 \pm 1.10 \\
3.45 \pm 1.11 \\
\end{array}$ & $\begin{array}{l}F=0.466 \\
0.556\end{array}$ & $\begin{array}{l}4.19 \pm 1.59 \\
4.17 \pm 1.50 \\
4.13 \pm 1.54 \\
\end{array}$ & $\begin{array}{l}F=0.048 \\
0.890\end{array}$ \\
\hline $\begin{array}{l}\text { Workplace during the pandemic } \\
\text { unemployed } \\
\text { work at home } \\
\text { I work outside, and I have been in contact with many people } \\
\text { I work outside, and I have been in contact with few people } \\
\text { health practitioner }\end{array}$ & $\begin{array}{l}3.18 \pm 1.14 \\
3.44 \pm 1.08 \\
3.73 \pm 1.17 \\
3.36 \pm 1.08 \\
3.86 \pm 1.00\end{array}$ & $\begin{array}{l}F=6.417 \\
<0.001 * *\end{array}$ & $\begin{array}{l}4.07 \pm 1.39 \\
3.89 \pm 1.58 \\
4.61 \pm 1.52 \\
4.64 \pm 1.62 \\
4.02 \pm 1.89\end{array}$ & $\begin{array}{l}F=3.705 \\
0.010 * *\end{array}$ \\
\hline $\begin{array}{l}\text { Family members working in the medical field } \\
\text { yes } \\
\text { no }\end{array}$ & $\begin{array}{l}3.56 \pm 1.14 \\
3.27 \pm 1.13\end{array}$ & $\begin{array}{l}T=2.772 \\
0.010^{* *}\end{array}$ & $\begin{array}{l}4.22 \pm 1.62 \\
4.13 \pm 1.47 \\
\end{array}$ & $\begin{array}{l}T=0.626 \\
0.659\end{array}$ \\
\hline $\begin{array}{l}\text { Tested for COVID-19a } \\
\text { yes } \\
\text { no }\end{array}$ & $\begin{array}{l}3.47 \pm 1.20 \\
3.29 \pm 1.08 \\
\end{array}$ & $\begin{array}{l}T=1.703 \\
0.054\end{array}$ & $\begin{array}{l}4.65 \pm 1.55 \\
3.69 \pm 1.36 \\
\end{array}$ & $\begin{array}{l}T=7.324 \\
<0.001^{* *}\end{array}$ \\
\hline $\begin{array}{l}\text { Family history of COVID-19a } \\
\text { yes } \\
\text { no }\end{array}$ & $\begin{array}{l}3.26 \pm 1.16 \\
3.52 \pm 1.11\end{array}$ & $\begin{array}{l}T=-2.483 \\
0.013^{* *}\end{array}$ & $\begin{array}{l}4.49 \pm 1.51 \\
3.79 \pm 1.47\end{array}$ & $\begin{array}{l}T=5.210 \\
<0.001 * *\end{array}$ \\
\hline
\end{tabular}

${ }^{\mathrm{a}} p$-value calculated using the Mann-Whitney $\mathrm{U}$ test, ${ }^{\mathrm{b}} p$-value calculated using the Kruskal-Wallis test, ${ }^{* *}$ significant at a level of $p<0.05$.

\section{Discussion}

The current global crisis brought on by COVID-19 has had a devastating effect on every aspect of one's well-being. Many people succumb to death within a short period of time. Fighting this pandemic has been a significant challenge. This will depend mainly on the behavior and the will of the public to curb the virus's spread. Thus, this study was conducted to determine the general knowledge and attitude of the population toward reporting potential COVID-19 symptoms. In this study, the level of knowledge regarding COVID-19 was low (52.2\%), while $47.8 \%$ were at a good knowledge level. The mean knowledge score was 3.38 (SD 1.14) out of 5 points. Consistently, insufficient knowledge among the general population was also reported by Rabbani and Al Saigul [20], as well as Haftom et al. [19]. The participants of this study showed poor knowledge compared to other studies. This might be justified as the participants of this study are general population, while the participants of other studies were medical field workers [20]. Another factor that can contribute to the low knowledge level of the participants in this study is the limited number of questions, as there were only three questions to evaluate their knowledge compared to other studies that used thirteen questions [19].

On the other hand, several papers reported good knowledge concerning the pandemic, which was in contrast with our report $[11,21-23]$. Furthermore, we know that gender and education level are significant factors associated with knowledge. This finding followed the data from several published papers [11, 19, 21, 22]. In a study by Wolf et al. [24], they reported that age was a significant factor for knowledge, which was similar to the studies published in Ethiopia [19], Malaysia [21], China [22], as well as in Cameroon [23]. However, this is in contrast with our study, as we found no significant association between the knowledge score and the age group. We also noted that workplace, family members working in the medical field and a family history of COVID-19 were the remaining factors associated with knowledge.

Concerning the attitude toward the COVID-19 pandemic, this was found to be deficient. Almost two-thirds (64.1\%) of the respondents were classified as having negative attitudes, while the remaining $35.9 \%$ were optimistic (mean: 4.16; SD 1.53 out of 9 points). Various papers have reported a positive attitude toward the pandemic, which contradicted our report [11, 21, 23, 24]. We also noted that the residence region was one of the factors that was associated with attitude. This is comparable to the paper by Alhazmi et al. [11], as they also documented regions that were significantly associated with attitude. Other factors of attitude that we identified were workplace, those tested for COVID-19 and those with a family history of the disease. Some authors documented that the level of education was also a factor of attitude [19, 21]. However, this is not true in our study, as the difference between attitude and education level was not significantly different. The low score of participants' attitudes in this study can be due to the types of questions, as the first question had multiple correct answers, which might confuse the participants. Question five also asked the participants about whether they changed their habits in exercising and eating healthy foods. Question six asked them if they were smokers and had quit smoking. These two questions might not be relevant to attitude, as they may be related to the participant's habits, and most people did not change their habits during the pandemic.

Moreover, question seven asked the participants if they are willing to get the COVID-19 vaccine. Saudi Arabia started the vaccine campaign on December 17,2020 , while this study was conducted between the period from December 15, 2020, to January 15,2021 . For this reason, most participants were not sure if they would get the vaccine or not. Furthermore, the priority of vaccination was given to older people and people with chronic diseases, and there are only 37 participants in this study that belong to the age group 51-65 years. These reasons could justify the uncertainty of most participants, as they still had time to decide.

Moreover, Siddiqui et al. [25] documented a significant relationship between knowledge and attitude. However, in our study, no significant correlation was observed between knowl- 
edge and attitude. A similar finding was also documented by Azlan et al. [21], which reported that no significant relationship was detected between attitude and knowledge scores.

It can be noted that the respondents were aware that the main transmission of COVID-19 happens through the respiratory droplets of infected persons when sneezing or coughing, followed by direct contact with infected persons and contact with contaminated objects and surfaces, where it may take up to two weeks for the incubation period. Various papers reported that the general public knows that COVID-19 is an airborne disease $[19,21,23]$. Ngwewondo et al. (2020) [23] had also demonstrated that kissing and handshaking with infected persons and touching contaminated surfaces could spread the virus, which was indicated in our report. This might not be surprising, as the media had a role in spreading the knowledge of COVID-19.

Immediate action is required once there is a suspicion of COVID-19 infection. In this study, the most commonly stated action to be taken in experiencing symptoms was self-isolation, followed by drinking plenty of water and eating healthy foods. Knowledge regarding self-isolation was also in accordance with the study by Hafton et al. [19] and Azlan et al. [21].

Interestingly, in this study, $72.4 \%$ of the subjects were not afraid at all or were a little afraid of COVID-19 infection, with only $5.6 \%$ being afraid. This is not consistent with the papers by Wolf et al. [24], as well as Rabbani and Al Saigul [20]. Both papers indicated that the respondents were worried or very worried about the virus. The participants of these two studies might be worried about COVID-19 as they were done before the vaccine's availability. On the other hand, the vaccine was available during this study, which might influence the participants to not worry about getting infected.

Finally, we found that $7.1 \%$ of the participants stopped smoking due to a fear of quickly becoming infected by the virus, while $10.1 \%$ did not see the relation. On the other hand, Bommele et al. [18] offered conflicting reports. Based on their investigation, $14.1 \%$ of smokers reported smoking less due to pandemic, but $18.9 \%$ of smokers reported smoking more, suggesting that stress might have contributed to the increased and decreased level of smoking. Undeniably, the evidence linking smoking to the severity of COVID-19 disease potentially added to these smokers' greater motivation to quit [26].

One of the study's limitations was not asking the participants whether the COVID-19 infection was during the first wave or the second wave. The COVID-19 tests were done by the ministry of health in Saudi Arabia, which we assumed to be done using a PCR test. Moreover, as the questionnaire was distributed via social media, there is always a risk of bias in responding to these questions, as there is a lack of motivation. As a result, this sample might not represent the target group.

\section{Conclusions}

The knowledge and attitude toward reporting potential COVID-19 symptoms were suboptimal in this tested population in the Al-Ahsa governorate. Those being male, a university degree holder in the medical field, a health practitioner and having a family member working in the medical field demonstrated better knowledge than the rest, while those tested for COVID-19 and those with a family history of the disease positively influenced one's attitude. Better knowledge and attitude among the general population are necessary to curb the crisis. Thus, addressing these gaps is vital in the community. Educational campaigns targeting to improve knowledge and attitude, especially in rural areas with high numbers of less-educated people, could positively affect this process.

Acknowledgements. The researchers would like to express their thanks to all the participants for their cooperation.

Abbreviations: MERS-CoV - Middle East Respiratory Syndrome; SARS-CoV - Severe Acute Respiratory Syndrome; COVID-19 - Coronavirus disease 19; NAATs - nucleic acid amplification tests; RT-qPCR - real-time reverse transcription-polymerase chain reaction; CT - computerized tomography; HCW - health care workers; SPSS - Statistical Package for the Social Sciences.

Source of funding: This work was funded from the authors' own resources.

Conflicts of interest: The authors declare no conflicts of interest.

\section{References}

1. CDC. Human Coronavirus 2020 [cited: 18.02.2021]. Available from URL: https://www.cdc.gov/-coronavirus/types.html.

2. Shereen MA, Khan S, Kazmi A, et al. COVID-19 infection: origin, transmission, and characteristics of human coronaviruses. J Adv Res 2020; 24: 91-98.

3. Rothe C, Schunk M, Sothmann P, et al. Transmission of 2019-nCoV infection from an asymptomatic contact in Germany. N Engl J Med 2020; 382(10): 970-971.

4. Michelen M, Jones N, Stavropoulou C. In patients of COVID-19, what are the symptoms and clinical features of mild and moderate cases? CEBM [Internet] 2020 [cited: 18.02.2021]. Available from URL: https://www.cebm.net/covid-19/in-patients-of-covid-19-whatare-the-symptoms-and-clinical-features-of-mild-and-moderate-case/.

5. People's Republic of China. New coronavirus cases rise to 571 in Chinese mainland. National Health Commission of the People's Republic of China Beijing (CHN); 2020 [cited: 18.02.2021]. Available from URL: http://en.nhc.gov.cn/2020-01/23/c_76004.htm.

6. Guan W, Ni Z, Hu Y, et al. Clinical characteristics of coronavirus disease 2019 in China. N Engl J Med 2020; 382(18): 1708-1720.

7. Wang W, Xu Y, Gao R, et al. Detection of SARS-CoV-2 in different types of clinical specimens. JAMA 2020; 323(18): 1843-1844.

8. McIntosh K. Coronavirus disease 2019 (COVID-19): Epidemiology, virology, and prevention. UpToDate [Internet] 2021 [cited: 18.02.2021]. Available from URL: https://www.uptodate.com/contents/covid-19-epidemiology-virology-and-prevention.

9. Corman VM, Landt O, Kaiser M, et al. Detection of 2019 novel coronavirus (2019-nCoV) by real-time RT-PCR. Euro Surveill 2020; 25(3): 2000045.

10. Jiang R. Inside China and COVID-19: Questions and answers. Travel Med Infect Dis 2020; 34: 101640.

11. Alhazmi A, Ali MHM, Mohieldin A, et al. Knowledge, attitudes and practices among people in Saudi Arabia regarding COVID-19: a crosssectional study. J Public Health Res 2020; 9(3): 1867.

12. Guo X, Wang J, Hu D, et al. Survey of COVID-19 disease among orthopaedic surgeons in Wuhan, People's Republic of China. J Bone Joint Surg Am 2020; 102: 847-854.

13. Karadaş Ö, Öztürk B, Sonkaya AR. A prospective clinical study of detailed neurological manifestations in patients with COVID-19. Neurol Sci 2020; 41(8): 1991-1995.

14. Qiu H, Wu J, Hong L, et al. Clinical and epidemiological features of 36 children with coronavirus disease 2019 (COVID-19) in Zhejiang, China: an observational cohort study. Lancet Infect Dis 2020; 20(6): 689-696.

15. Šljivo A, Kačamaković M, Quraishi I, et al. Fear and depression among residents of Bosnia and Herzegovina during COVID-19 outbreakinternet survey. Psychiatr Danub 2020; 32(2): 266-272. 
16. Ammar A, Brach M, Trabelsi K, et al. Effects of COVID-19 home confinement on eating behaviour and physical activity: results of the ECLB-COVID19 international online survey. Nutrients 2020; 12(6): 1583.

17. Górnicka M, Drywień ME, Zielinska MA, et al. Dietary and lifestyle changes during COVID-19 and the subsequent lockdowns among Polish adults: a cross-sectional online survey PLifeCOVID-19 study. Nutrients 2020; 12(8): 2324.

18. Bommele J, Hopman P, Walters BH, et al. The double-edged relationship between COVID-19 stress and smoking: implications for smoking cessation. Tob Induc Dis 2020; 18(63): 1-5.

19. Haftom M, Petrucka P, Gemechu K, et al. Knowledge, attitudes, and practices towards COVID-19 pandemic among quarantined adults in Tigrai Region, Ethiopia. Infect Drug Resist 2020; 13: 3727.

20. Rabbani U, Al Saigul AM. Knowledge, attitude and practices of health care workers about corona virus disease 2019 in Saudi Arabia. J Epidemiol Glob Health 2021; 11(1): 60-68.

21. Azlan AA, Hamzah MR, Sern TJ, et al. Public knowledge, attitudes and practices towards COVID-19: a cross-sectional study in Malaysia. PLOS ONE 2020; 15(5): e0233668.

22. Yue S, Zhang J, Cao M, et al. Knowledge, attitudes and practices of COVID-19 among urban and rural residents in China: a cross-sectional study. J Community Health 2020: 1-6, doi: 10.1007/s10900-020-00877-x.

23. Ngwewondo A, Nkengazong L, Ambe LA, et al. Knowledge, attitudes, practices of/towards COVID 19 preventive measures and symptoms: a cross-sectional study during the exponential rise of the outbreak in Cameroon. PLoS Negl Trop Dis 2020; 14(9): e0008700.

24. Wolf MS, Serper M, Opsasnick L, et al. Awareness, attitudes, and actions related to COVID-19 among adults with chronic conditions at the onset of the US outbreak: a cross-sectional survey. Ann Intern Med 2020; 173(2): 100-109.

25. Siddiqui AA, Alshammary F, Amin J, et al. Knowledge and practice regarding prevention of COVID-19 among the Saudi Arabian population. Work 2020; 66(4): 767-775.

26. Alqahtani IS, Oyelade T, Aldhahir AM, et al. Prevalence, severity and mortality associated with COPD and smoking in patients with COVID-19: a rapid systematic review and meta-analysis. PLOS ONE 2020; 15(5): e0233147.

Tables: 6

Figures: 2

References: 26

Received: 17.03 .2021

Reviewed: 23.04 .2021

Accepted: 08.06.2021

Address for correspondence:

Abdullah Almaqhawi, MD

Department of Family Medicine and Community

College of Medicine

King Faisal University

P.O. Box No. 400 Al-Ahsa - 31982

Saudi Arabia

Tel: +966-13-5929922

E-mail: dr.akaam@hotmail.com 